\title{
Coming Together: papers from the Seventh Australian Library History Forum
}

\author{
Reviewed by Luke Trainor
}

Coming Together: papers from the Seventh Australian Library History Forum. Monash Occasional Papers in Librarianship, Recordkeeping and Bibliography. Edited by B. J. McMullin. Melbourne: Ancora Press, 1997.

The seven papers published here make a stimulating collection. Three deal with recordkeeping or archives. Michael Piggott surveys the history of Australian recordkeeping, arguing that the subject needs to be broadened and deepened, in particular with regard to personal recordkeeping, which can function as 'a way of evidencing and memorialising our lives'. He suggests some topics-the importance of women as record keepers, the history of document forgery and the phenomenon of time capsules. Jock Murphy provides a case study of the history of the manuscript collection at the State Library of Victoria, showing that although archives were deposited from the 1880 s, it was not until the late twenties and thirties that they attracted separate attention and the establishment of a group of archivists had to wait until the 1950s. Bruce Smith looks at the destruction of archives, providing a perspective that may have relevance to New Zealand. He traces in fascinating detail the process by which governments undertook salvage collections to recycle waste materials at the start of the Second World War. Old court documents were destroyed and government departments apparently provided material, despite a pre-existing policy that the Public Library Trustees had to be consulted and have any records examined before their destruction. A particular and crucial example of suspected document destruction is provided by Piggott's reference to the 1934-48 gap in the records of the NSW Aboriginal Welfare Board. This relates to the nationwide policy of Aboriginal child removal only now being subject, in limited fashion, to apology and redress.

There is a recurrent theme in the four papers on librarianship: the development of professionalism and the challenges to it down to the 
present. Mary Ronnie goes to the heart of the theme with her study of library education and the role of the New Zealand Library Association, in particular in the thirties and forties. In the late thirties there emerged a desire for a specific New Zealand training rather than relying on a British qualification administered at twelve thousand miles. It was not, however, to be an easy path. There were proposals from the Association's Training Committee but also from the four branches; there were New Zealand training and British qualifications together but also at local level senior librarians providing their own training schemes. After much debate the first candidates for a new General Certificate started in 1942. It was not until 1946 that a Library School was established within the National Library Service and a post-graduate diploma commenced. Throughout this account Ronnie gives a proper emphasis to the role of Jessie Carnell, and evaluates the achievements, recognising the problems of a low completion rate and the difficulties of balancing the demands of theory and practice, especially in regard to the very different types of libraries for which the students were being prepared. She provides the background to the reorganisation of library education with the certificate at Wellington Teachers' College and the diploma at Victoria University. In this way the Library Association gradually moved from the scene. This is a story well told of how the Library Association, against considerable odds, established professional training for its members and helped build the status of the profession.

Three papers on the history of Australian librarianship take up the formation of, and threats to, professionalization. Brian Hubber uses a rich store of Melbourne archives to analyse the type of applicants for a library post in 1884. the hundred applicants had a diversity of backgrounds, but Hubber is able to demonstrate a proto-professionalism already present. Michael Talbot follows with a study of the Library Association of Australasia which was formed in 1896 but was moribund before the NZLA was formed in 1910. Talbot goes far beyond a history of the organisation providing the reader with a rich account of libraries and librarians in the late nineteenth century. It is eminently timely, using as its peg the comments of Lord Dufferin to the Library Association in Britain in 1894: 'Great Britain alone is overwhelmed by a recurring deluge of 7000 new books ... It is you who evoke order out of chaos, who convert a mob into an army.' The survey of libraries is brought down to the present with a paper by Hans Lofgren on the impact in Victoria of the New Managerialism. This 
is an eminently clear explanation of the theories of what is termed in Australia 'economic rationalism' and what it means for libraries and the goals and methods that they have followed in the past. It is a well expressed critique drawn from a variety of perspectives. He points out the paradox of libraries being 'guided by non-market and largely nonquantifiable objectives grounded in the 'professionalism' of librarians.' He concludes that the purchaser-provider model does not work for libraries.

Conference papers are not always successful as books but this one has a coherence and an interest throughout all its papers that will recommend it to library users and, I imagine, to librarians as well.

Originally published in Kōtare 1, no. 1 (1998), pp. 110-112. 